\title{
Turizmi Etkileyen Avrupa Birliği Politikalarının Türkiye Turizm Politikaları ile Karşılaştırılması: AK Parti Dönemi
}

Zafer AKBAS 1 Çiğdem MUTLU ${ }^{2}$

\section{Özet}

Turizm, küreselleşmeyle birlikte dünya genelinde önemli bir endüstri haline dönüşmüştür. Avrupa Birliği, ortak bir turizm politikası ortaya koyamamış olsada, diğer politika başlıkları altında turizme yer vererek turizmi ön plana çıkarmaktadır. Aynı şekilde Türkiye'de, Avrupa Birliği üyelik sürecinde turizm politikalarını geliștirmeye çalışmaktadır. Bu kapsamda, Adalet ve Kalkınma Partisi iktidarının, 2002 yılından itibaren iyileştirme ve geliştirme çabaları bulunmaktadır. Bu dönemde, turizm alanında yapılan çalışmaların başarılı bir şekilde yürütüldüğü, ancak sürecin devam ettiği; bazı projeler ile anlaşmaların sürmekte olduğu saptanmıştır.

Çalışmanın amacı, Adalet ve Kalkınma Partisi döneminde gerçekleştirilen turizm faaliyet ve stratejileri ekseninde, Avrupa Birliği turizm politikaları ile Türkiye turizm politikalarının karşılaştırılması ve endüstriye yansımalarının tespit edilmesidir. Çalışmada bu süreçte daha önceki dönemlere nazara etkin politikalar izlendiği, her iki aktör özelinde de devam ettirilmesi gereken süreçlerin olduğu sonucuna ulaşılmıştır.

Anahtar Kelimeler: Turizm, Türkiye, Avrupa Birliği, AK Parti, Karşılaştırmalı Politika

\section{A ComparativeStudy Of EU Tourism Policies and Its Effects On Tourism With Turkish Tourism Policy: AK Party Period}

\section{Abstract}

Tourism has turnedinto a prominent industry around the world with globalization. Despite the fact that, EU has not been able to put forward a common tourism policy, they gave priority to tourism under other policy headlines. Turkey has been struggling to develop tourism policy within the course of European Union Membership.

Within this framework, there has been reformation and improvement initiatives by Adalet ve Kalkınma Partisi (Justice and Development Party) since 2002. The successive works in tourism area has been carried out and yet, continuation of the process: and some agreements with projects are stil being carried out has been prescribed within this period. The aim of this study is to compare tourism activities and strategies realized by Justice and Development Party and EU tourism policy and Turkish tourism policy and determine its effects on industry. Within the study, when compared to previous periods, more effective policy being carried out and both actors in the individual capacity have task to keep the progress have been resolved.

Key Words: Tourism, Turkey, European Union, AK Party, Comparative Politics

\section{Giriş}

Turizm, küreselleșme ile birlikte gelișerek bütün dünyada daha çok rağbet edilen bir endüstri olarak karşımıza çıkmaktadır. Bunun en önemli nedenleri arasında turizmin, kültürel, politik, sosyal ve ekonomi gibi diğer endüstrilerle bağıntılı bir endüstri olması yer almaktadır. Turizmin istihdam sağlaması, ödemeler dengesine

\footnotetext{
${ }^{1}$ Doç. Dr., Düzce Üniversitesi, Uluslararası İlişkiler Bölümü Öğretim Üyesi, zaferakbas@duzce.edu.tr

2 Öğr. Gör., Alanya Alaaddin Keykubat Üniversitesi Gazipaşa MRB MYO, Turizm ve Otel

İşletmeciliği Programı Öğretim Elemanı, cigdem.mutlu@alanya.edu.tr
} 
Yalova Sosyal Bilimler Dergisi

katkıda bulunması, sosyal ve kültürel açıdan gelişmeye hız kazandırması gibi benzer birçok sebepten ötürü ülkelerin önem verdiği endüstri olarak bilinmektedir.

Turizm endüstrisinde bilinen en geniş pazarın Avrupa Birliği (AB) ülkelerinde olduğu görülmektedir. $\mathrm{Bu}$ nedenle Türkiye üyelik sürecinde $\mathrm{AB}$ turizm politikalarına adapte olmaya çalışmaktadır. $\mathrm{AB}$ ve Türkiye turizm için ortak bir politika oluşturmamıştır, ancak endüstrinin katkılarının farkında olduğu bilinmektedir. $\mathrm{Bu}$ nedenle, gereken hassasiyeti göstererek endüstri için farklı düzenlemeler, kararlar, toplantılar ve projeler gerçekleştirmektedir.

Ayrıca, AB temel politikalarında turizm ile ilgili hükümlerin mevcut olduğu bilinmektedir. $\mathrm{Bu}$ politikalarda, endüstriyle ilgili olarak özellikle tüketicilerin korunması, çevre, ulaştırma, sosyal politika, eğitim, Avrupa turizminin tanıtılması, turizm istatistiklerinin geliştirilmesi ve bilgi teknolojilerinin yer aldığı görülmektedir.

Türkiye, turizm endüstrisinin önemini bilmesiyle birlikte, özellikle AB'ye uyum sürecinde, çalışmalarına hız kazandırdığ 1 görülmektedir. 2002 yılında AK Parti'nin iktidar olması ile birlikte turizm endüstrisinde çıkış yakaladığ görülmektedir. Türkiye'nin bu endüstrideki büyüme hızı tahmin edilenin de üzerine olmuş ve dünya turizminin büyüme ortalamasının iki katından da yüksek bir ivmeyle yükselmiştir.

$\mathrm{Bu}$ çalışmanın amacı, AK Parti döneminde gerçekleştirilen turizm faaliyetleri ekseninde, $\mathrm{AB}$ turizm politikaları ile Türkiye turizm politikalarının karşılaştırılmasıdır. Ayrıca, turizm politikalarının karşılaştııılmasıyla bu endüstriye yansıyan olumlu ve olumsuz sonuçların neler olduğunun tespit edilmesi de bir diğer amaç olarak belirlenmiştir.

\section{Avrupa Birliği Turizm Politikaları}

Avrupa Birliği, yakın bir tarihe kadar turizmin büyümesi ve gelişmesi konusuna ciddi bir şekilde yaklaşmamış ve turizmle dolaylı olarak ilgilenmiştir. Ancak, turizmin büyümesi ve ülkelere olan katkılarının anlaşılması, konunun önemini ortaya çıkarmıştır. Buna rağmen, Avrupa Birliği'nin her ne kadar turizmle ilgili çalışmaları olsa da bu alandaki faaliyetleri düzenleyen ortak bir politikası henüz oluşmuş değildir.

Avrupa Birliği'nin temelini oluşturan Roma Antlaşması'ndan sonra imzalanan Avrupa Tek Senedi'nde ve kurucu antlaşma olan Maasricht Antlaşması'nda tarım, sanayi, çevre, ulaştırma gibi başlıklarla alakalı birçok ortak politikanın yer aldığı görülmektedir. Ancak, bu başlıklar arasında her ne kadar turizm başlığı olmasa da Avrupa Birliği turizmin kültürel, ekonomik ve sosyal yönlerden önemini kabul ettiği görülmektedir (Ural, 2008: 4).

1980'li yıllara kadar, AB'de turizm politikalarını etkileyen alanların; istihdam, çevre, kültür ve tüketici politikaları çerçevesinde şekillenmiş olduğu görülmektedir. 1980'li yılları izleyen dönemde de turizm sektörünün, bir başlık halinde, politika oluşturma sürecinin içerisine dâhil olmaya başladığıgörülmektedir (Ateşoğlu, 2006: 43-44). 
Yalova Sosyal Bilimler Dergisi

1990'lı yıllardan sonraki dönemler incelendiğinde, turizm sektörü için daha ciddi adımların atıldığı görülmektedir (Paksoy, 2005: 58). 1990 yılı "Avrupa Turizm Y1lı" olarak ilan edilmiştir. "Avrupa Turizm Yılı" ilanının amacı, turizmin entegrasyon vesilesi olma niteliğini öne çıarmak ve turizmin ekonomik, sosyal katkılarına dikkati çekmektir (Commission of the European Communities, 1991: 13). Bu bağlamda, ilan hem Avrupa'da hem de üçüncü ülkelerde gerçekleştirilmesi düşünülen tanıtıma da katkı sağlamıştır (Avcıkurt, 1997: 75).

Turizm ile ilgili bütün alanlarda ortak çalışma yapmak, turizmi geliştirmek turizmi çeşitlendirmek amacıyla 1990 yılında "Turizm Eylem Planı" adı altında bir plan hazırlanmıştır. Bununla birlikte, Turizm Eylem Planı (1991) ve Turizm Destekleme Eylem Planı (1993-1995) da turizmi geliştirmek için hazırlanmış diğer planlar arasında yerini almıştır.

Avrupa Parlamentosu, AB'nin ortak turizm politikası için bir rapor hazırlanmasını istemiş ve bunun sonucunda McMillan Scott Raporu düzenlenmiştir. $\mathrm{Bu}$ rapor, turizm ile alakalı uygulamalarda fikir ve bilgi alışverişi olması, turizm ile ilgili alanlardaki değişikliklerin takip edilmesi gibi önemli konuları içermektedir. Ayrıca raporda genelde turizm sektörünün ekonomik niteliğinin ön plana çıktı̆̆ı, ancak ekolojik veya sosyal yönlerinin irdelenmediği de belirtilmiştir (Sivil, 2007: $55)$.

AB Komisyonu, Nisan 1995'te "Yeşil Kitap" adlı bir rapor yayımlayarak, "Birliğin Turizm Alanındaki Rolü" üzerine çalışmalara başlamış ve bunun, endüstriye yönelik hazırlanan ilk yasal düzenleme olduğu söylenmiştir (Ural, 2008: 28). Bununla birlikte, raporda, KOBI'lerin desteklenmesi ve turizmin kalitesinin artırılması yönündeçalışılmasıgerektiğine vurgu yapılmıştır (Commission of the European Communities, 1995: 3). Ayrıca, Yeşil Rapor kapsamında, AB'nin ilk Turizm Teşvik Programı olarak bilinen Philoxenia-Konukseverlik Programı'nın oluşturulduğu bilinmektedir (Köfteoğlu, 2003: 32).

2000'li yıllar değerlendirildiğinde, turizm sektörü ile alakalı, istihdam, kırsal kalkınma, sosyal, kültürel gelişmeler ve ekonomiye olan etkileri gibi konular Avrupa'nın gündeminde yer edinmektedir. Bu konuların hala tartışılmaya devam ettiği görülmektedir.

Avrupa Konseyi, 2000 yılında Lizbon'da toplanarak, turizm adına yeni bir strateji hedefi ortaya koymuştur. $\mathrm{Bu}$ bağlamda hedef, Avrupa Birliği'nin ekonomisini dünya üzerinde, rekabet edebilir ve dinamik hale getirmektedir. Bunun sonucunda da turizme ve turizme destek veren işletmelerin politikalarına ayrı ciddiyetle yaklaşmayı hedeflemiştir (Commission of the European Communities, 2002: 5). AB Komisyonu, 2005 yılında, yenilenmiş AB Turizm Politikası adı altında bir başka tebliğ yayınlayarak, Avrupa turizminde rekabeti arttırarak hem Avrupa hem de dünya turizminin büyümesini devam ettirmeyi amaçlamıştır. Böylece, yeni iş imkânları oluşturarak istihdamın artırılmasını da bir diğer hedef olarak belirlemiştir (Verheugen, 2005: 3).

Avrupa turizm politikası çerçevesinigüncelleştirmek için 2010 y1lında, Avrupa Turizm Paydaşlar konferansı düzenlenmiştir. Konferans sonunda, otel sınıflandırmaları, Avrupa Etiketi oluşturmak, turizme finansal destek, özel ve kamu kuruluşlarının birlikte hareket etmesi gibi fikirler ön plana çıkmıştır. Bununla 
Yalova Sosyal Bilimler Dergisi

birlikte, vize gereken ziyaretçiler için AB'ye girişte, vizelerin kaldırılması, ucuzlaması, vize işlemlerinin kolaylaştırılması gibi konularda düzenlemeler yapılması gerekliliğgi de tartışmaya açılmıştır.

AB'de henüz ortak bir turizm politikasının oluşturulmaması, turizmin ciddiye alınmadığ Çünkü turizmin, diğer birçok farklı endüstri ve alanlardaki gelişmeler ve değişmeler ile bağıntılı olması göz önünde bulundurulduğunda, $\mathrm{AB}$ temel politikalarında turizm hükümlerinin varlığı görülmekte ve bu durumun $\mathrm{AB}$ tarafindan önemsendiği anlaşılmaktadır (Yağc1, 2003: 212). AB müktesebatı çerçevesinde, $A B$ temel politikalarında yeralan turizm ile ilgili hükümlerin; çevre, tüketicinin korunması, ulaştırma, sosyal-kırsal-kültürel gelişim, eğitim, istatistik, serbest dolaşım gibi politika metinlerinde yer aldığı görülmektedir.

AB'nin turizm ile ilgili dolaylı politikalarının doğrudan politikalarından fazla olduğu görülmektedir. Turizmin farklılık içermesi ve heterojen olması, yani kendine özgü niteliklerinin varlığı böyle bir durumu ortaya çıkarmaktadır. AB turizm politikalarını çevre, ulaştırma ve benzeri alanlardaki politikaların dolaylı olarak etkilediği bilinmektedir (Arslan, 2014: 432).

AB'nin önem verdiği çevre politikalarının temelinde "kirleten öder" prensibinin hâkim olduğu bilinmektedir. Bununla birlikte, $A B$, sürdürülebilir çevre konusuna da özellikle vurgu yapmaktadır. Bu bağlamda AB'nin, turizm endüstrisine katkı sağlayan ve çevre politikasıyla ilgilibilinen temel eylem maddelerivardır. Bunlar, kıyı ve dağlık alanlarda kitlesel turizm için idare, yönetim ve planlamaya daha çok önem verilmesi, yönetilmesi ve geliştirilmesi, sürdürülebilir turizmi geliştirmek ve turizmi ve turizm ürünlerini çeşitlendirmek, ziyaretçi bilincini arttırmak, çevresel kaygıyı yok etmek veya en aza indirgemek, ziyaretçi sorumluluğunu sağlamaktır (Karakuş, 2003: 21).

Çevre ile ilgili eylemlerin uygulama koşullarına bakıldığında ise, bunların AB finansmanı yoluyla gerçekleştirildiği görülmektedir. Turizm sektöründe bir proje ortaya koymak için destek arayışı içerisinde olan herkes, bu yapısal fonlar dâhilinde, en iyi çevresel seçenekleri gözönünde bulundurarak hareket etmesi gerekmektedir (Beken, 2007: 67).

AB ulaştırma politikasının amacı ise, ulaşım sistemlerinin, toplumun ekonomik, sosyal ve çevre ile ilgili ihtiyaçlarını giderebilmesini sağlamak olarak vurgulanmaktadır (European Commission, 2006: 6). Turizm hareketlerinin ulaşım olmadan gerçekleştirilmesi imkânsızdır ve bu bağlamda ulaşımın geliştirilmesi, yenilenmesi endüstriye hareketlilik kazandıracaktır. Havayollarında bilgisayar tabanlı rezervasyon sistemlerinin işlemleri hızlandırması, rekabetle birlikte havayolları biletlerinin ucuzlaması, havayolu ile ulaşımın zamandan kazandırması, kruvaziyerturizmin yaygınlaşması gibi birçok imkânın gelişmesi en önemli örnekler arasında yer almaktadır.

Avrupa Konseyi, "Avrupa Bir Ortak Miras” adında başlattığı kampanyayla kültürel ortam oluşturmaya çalışmıştır. Bu planın amacı, Avrupa'da kültürel, doğal ve tarihi miras konusunda bilinç uyandırmak, kültür çeşitliliğine değer vermek şartıyla ülkelerarası bütünleşme ortamı oluşturmak, miras olarak değerlendirilen sit alanları, sanat eserleriyle beraber kültürel, sosyal, geleneksel, manevi ve dini 
Yalova Sosyal Bilimler Dergisi

değerleri ortaya çıkararak farkındalığı artırmak ve kültürel turizmi ileriye taşımak olarak belirlenmiştir (Emekli, 2005: 102). Ayrıca, RAPHAEL Avrupa kültürel mirasının korunması programı ile Avrupa Kültür Ödülü ve Avrupa Kültür Şehri uygulamalarını faaliyete geçirmiş ve en iyi kültürel turizm ürünlerinebu isim ve nitelikler verilmiştir (Commission of the European Communities, 2004: 6).

Kültürel, kırsal, sosyal turizmin geliştirilmesi politikasında; turizm endüstrisinin en önemli temeli olarak görülen Avrupa kültürü ve mirası yer almaktadır. Bu bağlamda, Avrupa'nın, bu değerleri, ziyaretçiler açısından Avrupa şehir ve bölgelerinin çekiciliğini ve Avrupa bilincini üst noktalara taşıdığı görülmektedir. Bununla birlikte, topluluk tarafindan Avrupa kültür ve mirasının, turizm içinönem ve değerinin benimsetilmesi hususunda aktif rol oynadığı deklare edilmektedir. Kültürel olarak, müzelere, tarihi değerlere sahip çıkılması, bu kapsamda tarihi eser niteliğindeki binaların özellikleri bozulmadan otellere veya başka konaklama tesislerine, konser, tiyatro gibi alanlara dönüştürülmesi gibi çeşitli eylemler planlanmakta ve mali destek verilmektedir. Buna istinaden, bu faaliyetlerden en çok yararlananın ise turizm endüstrisi olduğu söylenebilir (Beken, 2007: 68).

AB'nin hedefleri arasındaki bir diğer politika ise, alternatif turizm faaliyetleri çerçevesinde, kırsal açıdan gelişmektir. Topluluğun kırsal turizme elverişli ve bu işi iyi bir şekilde gerçekleştiren yörelere destek verilmesi, teşvik edilmesi, yörelerin örnek olarak sunulması, tanıtılması, eğitim verilmesi, pilot bölge eylemleri ile yerel, bölgesel ve Avrupa düzeyinde işbirliğinin sağlanması hususuna oldukça önem verdiği ve ilgilendiği görülmektedir (Commission of the European Communities, 1996: 22).

Sosyal turizmin, engelli, yalnız veya genç çocuklarıyla yaşayan ailelerin, emekli ve üçüncü yaş grubunda olan, fakat maddi açıdan sıkıntı yaşayan kişi veya kişiler gibi değişik birçok nedenlerle turizm hareketlerine, sosyal hayata katılamayanlar için oluşturulduğu bilinmektedir (Commission of the European Communities, 1991: 31). Bu kapsamda, Avrupalı engelli vatandaşların, turizm hareketleri içerisinde yer almalarını sağlamak, teşvik etmek ve gereken yasal, mali ve teknik düzenlemelerin oluşturulmasını sağlamak hedeflenmektedir. Bununla birlikte, asıl hedef ise, Avrupa vatandaşlığına güç kazandırmak ve vatandaşların sosyal olarak gelişimlerine destek olmaktır (Commission of the European Communities, 2002: 42).

Avrupa vatandaşlarının tüketici haklarının korunduğuna dair garanti vermek üzere çeşitli politikalar oluşturulduğu bilinmektedir. Bu bağlamda, AB'nin, turistleri tüketici olarak gördüğü turistlerin haklarını garanti altına alarak korumayı amaçladığı görülmektedir (Karakuş, 2003: 22). Turizm endüstrisini etkileyen $A B$ tüketici politikasının ana faaliyet alanlarının; tüketiciyi koruma standartları ile ürün/hizmet hususunda tüketiciye bilgi vermeolmak üzere iki başlık altında sınıflandırılmaktadır. Ayrıca, AB'de turist hakları, tüketici hakları çerçevesinde koruma altına alınmaktadır (Çiçek ve Özgen, 2001: 145).

Serbest Dolaşım Politikası; AB üye ülkeleri arasındaki serbest dolaşım hakkının olması, turizm endüstrisinde de eğitim açısından gelişmiş kişi veya yatırımcıların AB üyesi ülkelerde herhangi bir engel olmadan çalışmasını sağlamayı 
Yalova Sosyal Bilimler Dergisi

amaçlamaktadır. Buna istinaden, bu politikanın turizmi olumlu yönde etkilemesi kaçınılmazdır (Arslan, 2014: 432).

Avrupa Birliği ortak politikalarından Mesleki Eğitim ve Öğretim, kişinin mesleğiyle alakalı alanda yeterli teknik, beşeri ve kavramsal yetenek ve beceri kazandırma amacı çerçevesinde oluşturulmuştur. Bu bağlamda, kişilerin yeterli yetkinliğe sahip olarak, daha kalifiye elemanlar sınıfına katılımları sağlanacaktır. Günümüzde en önemli sorun olarak bilinen kalifiye eleman eksikliğinin bu şekilde giderilmeye çalışılması amaçlanmaktadır.

Komisyon, Avrupa Mesleki Eğitimi Geliştirme Merkezi'nin (CEDEFOP) de katkılarıyla, Birlik seviyesinde, sekiz adet turizm ile ilgili meslekler için serbest dolaşımın geliştirilmesine olanak sağlayacak önlemler almıştır. Bu mesleklerin; resepsiyonist, barmen, garson, kat görevlisi, şef ve şarap sorumlusu olduğu açıklanmıştır. Ayrıca, Birlik üyesi olan ülkelerde nitelik olarak uyumlaştırılmalarının sağlanmasına olumlu katkılar sunmaktadır (Avcıkurt, 1997: $88)$.

AB'nin kendi içinde ortak Avrupa turizmi fikri ortaya çıkmaya başlamış ve böylece Avrupa'nın ortak tanıtıma daha çok önem vermeye başladığı görülmüştür. (http://www.euroacademic.org/tr, e.t. 10.11.2014). Bununla birlikte, Avrupa Komisyonu, Avrupa'yı bir turizm destinasyonu olarak tanıtmasını sağlayacak www.visiteurope.com isimli sitenin gelişmesi için maddi olarak destek vermektedir. Ayrica, bu site Avrupa Seyahat Komisyonu ve ulusal turist ofisleriyle beraber yönetilmekte ve hizmete sunulmaktadır (Paksoy, 2005: 95).

Avrupa Topluluğu'nunilk zamanlarından günümüze, Topluluk politikaları ile ilgili kararlar, bu kararların planlanması, uygulanmasının güvenli ve karşılaştırılabilir istatistiklere dayandırılmasının gerekliliği Turizm İstatistiklerinin Geliştirilmesi kapsamında vurgulanmıştır. Bu gerekliliğin yerine getirilmesi amaciyla, Avrupa Birliği düzeyinde, Avrupa İstatistik Sistemi (AİS) kurulmuştur (Türkiye İstatistik Kurumu, 2014: 1). Böylece turizm endüstrisi ile ilgili istatistikler, Avrupa İstatistik Sistemi tarafindan düzenlenmektedir. Ayrıca, AB turizmine dair mevcut bilgilerin de uyumlaştırdığı görülmektedir (European Communities, 1995: 33).

Turizm, emek yoğun endüstriler arasında yer almaktadır ve bu sebeple, AB'nin, yeni üye ve aday ülkelerde turizmin geliştirilmesi ve yaygınlaştırılmasına destek verdiği görülmektedir. Turizm, bölgesel kalkınma ve istihdam oluşturma yönünden önemli bir endüstridir. Ayrıca, turistlerin gerçekleştirdiği harcamalar, yeni üye ve aday ülkelere dolaylı yoldan sermaye aktarımına da imkân vermektedir. Bu bağlamda, ülkelerin ödemeler dengesine katkı sağladığı ortaya çıkmaktadır (Ateşoğlu, 2006: 36).

\section{Türkiye'nin Turizm Politikaları ve Gelişimi: Ak Parti Dönemi}

\subsection{Türkiye Turizm Politikaları}

Turizm, birçok ülkede olduğu gibi Türkiye'de de oldukça yeri ve önemi olan bir endüstri konumundadır. Türkiye sahip olduğu kültürel değer ve mirasları, jeopolitik konumu, doğal güzellikleri gibi özelliklerinden dolayı turizme oldukça 
Yalova Sosyal Bilimler Dergisi

elverişli bir ülke olarak tanınmaktadır. Ayrıca, bu endüstrininoluşturduğu istihdam ve bu endüstriden elde edilen gelir de ülke ekonomisinde önemli oranda rol oynamaktadır.

Günümüzde, Türkiye'de imalat sanayinin ardından turizmin, döviz getirisi bakımından en önemli konumda yer aldığı görülmektedir (Çınar ve Hepaktan, 2007: 135). 1993 yılında turizmdeki doğrudan istihdamın toplam istihdam içerisindeki payı yüzde 3,56 olarak gerçekleşmiştir. Bu oranın Türkiye'de2001 yılında yüzde 5,10 ve 2010 yılında ise yüzde 6,70'lere ulaştığı görülmektedir. Ayrıca, endüstrinin dolaylı istihdamdaki payı 1993 yılında yüzde 8,90, 2001 yılında yüzde 12,76 ve 2010 y1lında ise yüzde 19,81 seviyelerinde gerçekleşmiştir. Bununla birlikte, toplam istihdam içerisindeki payıda yüzde 12,46'dan yüzde 26,51'e çıkmıştır (Avc1 ve Yanardağ, 2012: 45). Bu veriler dikkate alındığında AK Parti dönemiyle birlikte turizme verilen önemin arttığı ve turizmin istihdamdaki pay oranlarının giderek yukarı yönlü olduğu görülmektedir.

Türkiye turizm politikaları cumhuriyet öncesi dönem, planlı dönem öncesi (1923-1963), planlı dönem ve sonrası (1963'den günümüze) olarak sınıflandırılabilir. Cumhuriyet dönemi öncesi dönemde, konaklama hizmetlerinin geliştiği söylenebilir. Planlı dönem öncesinde, 1923 yılında Türk Seyyahin Cemiyeti, 1939'da Turizm Müdürlüğü kurulmuş ve 1953 yılında Turizm Endüstrisini Teşvik Kanunu çıkarılmıştır. Ayrıca, turizme dair en önemli eylemlerden biri de, Ziraat Bankası ve diğer bankaların desteğiyle 1955 yılında Turizm Bankası'nın kurulmasıdır (Alaca, 1997: 48).

Planlı dönem, turizm endüstrisi adına asıl gelişmelerin gerçekleştiği dönem olarak bilinmektedir. Bu dönemde, 1963 yılında Turizm ve Tanıtma Bakanlığı, 1955 yılında Turizm Bankası, 1972 yılındaTürkiye Seyahat Acentaları Birliği (TÜRSAB) kurulmuştur. Bununla birlikte, 1982 yılında "Turizmi Teşvik Kanunu” yürürlüğe girmiş ve endüstride önemli teşvikler sağlanmıştır.

1963 yılından itibaren Beş Yıllık Kalkınma Planları hazırlanmıştır. 19631977 yılları arasında hazırlanmış olan bu kalkınma planlarında, ülke ödemeler dengesi açığını kapatmada turizmden faydalanabileceği, turist sayısı ve tüketim harcamalarının geliştirilmesi, kitle turizmi yatırımlarına ağılık verilmesi ve bu amaçla özel sektörün teşvik edilerek desteklenmesi hususuna vurgu yapılmıştır (Ünal, 2007: 31).

Kalkınma planları içerisinde, özellikle dokuzuncu kalkınma planının diğer planlardan farklı olduğu dikkati çekmektedir. AK Parti iktidarının koordinesinde yürütülen bu plan, yedi y1llık bir süre için oluşturulmuştur. Bununla birlikte, Dokuzuncu Kalkınma Planının vizyonunun "istikrar içinde büyüyen, gelirini daha adil paylaşan, küreselölçekte rekabet gücüne sahip, bilgi toplumuna dönüşen ve AB'ye üyelikiçin uyum sürecini tamamlamış bir Türkiye" şeklinde belirlendiği görülmektedir (Devlet Planlama Teşkilat1, 2006: 3). Buna istinaden, bu vizyon, aynı zamanda, AK Parti iktidarının $\mathrm{AB}$ uyumu doğrultusunda turizm faaliyetlerini sürdüreceğinin bir göstergesi olarak açılanmaktadır. 
Yalova Sosyal Bilimler Dergisi

\subsection{AK Parti Dönemi'nde Turizm Politikalarının Gelişimi}

AK Parti iktidarı döneminde turizm endüstrisindeki gelişmeler dikkat çekmektedir. Bu dönemde turizm dünyayla rekabet edebilecek en önemli üstünlük alanlarından birisi haline gelmiş̧ir. Hükümetin, turizm hareketleri adına yaptığı çalışmalar sonucunda, Türkiye'ye gelen turist sayısı ve gelirlerinde büyük oranda artışlar olduğunun altı Hükümet Programında çizilmiştir (II. Erdoğan Hükümeti Program1, 2014: 1).

AK Parti döneminde, Kültür ve Turizm Bakanlığı ile Vakıflar Genel Müdürlügü işbirliğinde yapılan restorasyon, proje ve uygulamasını bitirdiği eser sayılarının 3 binin üzerinde olduğu yönünde açıklama Hükümet tarafından yapılmıştır (II. Erdoğan Hükümeti Program1, 2014: 1). III. Erdoğan Hükümeti programında da "Komşularla Sıfır Sorun" politikasıyla komşu ülkelerle ticaret ve turizm artırılarak; sınır bölgelerinde önemli bir ekonomik dönüşümün başlatıldığı ifade edilmiştir (III. Erdoğan Hükümeti Programı, 2014: 1).

Turizm endüstrisinin hızla büyüdüğü ve bu kapsamda 2002 yılında Türkiye'ye gelen yabancı ziyaretçi sayısı 13,3 milyon kişi, turizm gelirleri ise 12,4 milyar dolar iken, 2013 yılında turist sayısının 34,9 milyon kişiye ve turizm gelirlerinin ise 32,3 milyar dolara çıktığı açılanmıştır. Bununla birlikte, sürdürülebilir bir yapıda turizmi çeşitlendirerek ve nitelikli hizmet kalitesi sunarak turizm gelirini istikrarlı bir şekilde yukarılara taşımayı öngören Türkiye Turizm Stratejisi hazırlanarak uygulamaya konulmuştur. Böylece, 2023 perspektifinde 50 milyon turist ve 50 milyar doları aşan bir turizm geliri elde edilmesi amaçlanmaktadır (62. Hükümet Programı, 2014: 123).

3 Ekim 2005 tarihinde, AB'ye tam üyelik müzakerelerinin başladığı açıklanmıştır. Bu bağlamda, 2009 yılında ilk kez münhasıran AB'den sorumlu bir Devlet Bakanı ve Başmüzakereci atanması ve 2011 yılında Avrupa Birliği Bakanlığı'nın kurulmasının, AK Parti iktidarının AB sürecine verdiği önemin kanıtı niteliğinde olduğu vurgulanmaktadır. Bununla birlikte, 2013 yılında Türk vatandaşlarının 3-3,5 yıl içinde Schengen ülkelerine vizesiz seyahat edebilmesine olanak verecek Vize Muafiyeti Diyaloğu'nun da resmen başlatıldığının açıklanması önemli bir adım olarak değerlendirilmektedir (62. Hükümet Programı, 2014: 23). Bununla birlikte, Schengen bölgesinde Vize Muafiyeti sağlanması çalışmalarına devam edildiği, 16 Aralık 2013 tarihli Vize Serbestisi Diyaloğu Mutabakat metni ve Geri Kabul Anlaşması'yla başlatılan müzakerelerde gereken sorumlulukların yerine getirilerek bu sürecin bitirilme aşamasına gelindiği açıklanmıştır (65. Hükümet Program1, 2016: 133).

AK Parti hükümeti; sanayi, turizm, tarım, altyapı, insan kaynakları ve sosyal kalkınma gibi birçok alanda, KOBI'lere, meslek ve sivil toplum kuruluşlarına, yaklaşık 11 bin proje kapsamında 1,8 milyar TL hibe kaynak kullandırdığ 1 ve bu katkıyla toplamda 3,3 milyar TL'ye yaklaşan bir kaynağ 1 da harekete geçirmiştir. Bununla birlikte, dünyadaki yeni turizm eğilimleri çerçevesinde kültür, kongre, sağlık, inanç, spor turizmi gibi alternatif turizm çeşitlerini geliştirerek Türkiye'ninher yöresini bir cazibe merkezi haline getirmeyi hedeflemektedir. Ayrıca, Türkiye'nin özellikle Avrupa'da, Kafkaslar'da ve Ortadoğu'da termal turizm ve sağlık turizmi hususunda önemli bir merkez olması yolunda adım attıkları 
Yalova Sosyal Bilimler Dergisi

ve çabaladıkları da elde edilen bilgiler arasında yer almaktadır (62. Hükümet Program1, 2014: 96).

AK Parti'nin, AB'ye üyelik sürecinde, diğer politikalarda olduğu gibi turizm politikalarında da $\mathrm{AB}$ 'ye uyum sağlama eşliğinde devam ettirdiği görülmektedir. AK Parti iktidarının, AB'nin kültür, sağlık, kültür vb. politikaları için oluşturduğu projelere uyum sağlayarak ve katılarak endüstriye hareketlilik getirdiği belirlenmiştir.

\section{AK Parti Dönemi Avrupa Birliği Turizm Politikaları İle Türkiye Turizm Politikalarının Karşılaştırılması}

Çevre Politikası; AB uyum süreci zarfında Türkiye'nin en çok önem verdiği politikalarından biridir. Çevrenin korunması ve gelecek nesillere aktarılabilmesi için AK Parti döneminde oldukça yoğun çalışmalar yapılmaktadır. Çevreyle ilgili hususlarda Türkiye'de, AB Entegre Çevre Uyum Stratejisi (2007-2023), Çölleşme ile Mücadele Türkiye Ulusal Eylem Programı, Ulusal Biyolojik Çeşitlilik Stratejisi ve Eylem Planı 2007, Ulusal İklim Değişikliği Strateji Belgesi (2010-2020), Mavi Bayrak Ödülü gibi politika belgeleri ön plana çıkmaktadır.

Türkiye'nin 2002 y1lında sahip olduğu mavi bayraklı plajları 151 iken 2013 yılında 397 mavi bayraklı plaja ulaşarak dünya sıralamasında 3. sıraya yükselmiştir. Ayrıca, 2002 yılında 964 olan korunan alan sayısı 2821'e yükseltilmiş ve 89 yeni kent ormanı kurulmuştur. Bu bağlamda, AK Parti'nin turizm adına büyük çevre atılımları gerçekleştirdiği söylenebilir (62. Hükümet Programı, 2014: 90-91).

2014 İlerleme Raporunda atık yönetimi hususunda, düzenli depolama tesislerinin $\mathrm{AB}$ standartlarına uyumuna dair çalışmaların olduğu ve devam edeceği açıklanmıştır (2014 İlerleme Raporu, 2014: 68). Bununla birlikte; AB fonlarından desteklenen "Kuş ve Habitat Direktiflerinin Uyumlaştırılması için Kurumsal Kapasitenin Geliştirilmesi Projesi"nin Mayıs 2013'te tamamlanmıştır (2013 İlerleme Raporu, 2013: 189). Ayrıca, Çevresel Etki Değerlendirmesi (ÇED) Yönetmeliği de Avrupa Birliği’ne uyum için yapılan çalışmalara gösterilen örnekler arasında yer almaktadır. Türkiye'nin, çevre değişikliği alanında tam hazırlıklı olmadığı, ancak 2014 yılında çevre mevzuatının uyumlaştırılması konusunda ilerlemeler olduğu görülmektedir (2015 İlerleme Raporu, 2015: 81).

Sürdürülebilir turizm çerçevesinde, çevreyi korumak, çevre bilincini artırmak ve bu alana dikkati çekmek, turizm işletmelerinin çevreye duyarlılıklarının teşvik edilmesi vb. amaçlarla konaklama tesislerine çevreye duyarlı konaklama tesisi belgesi (Yeşil Yıldız) verilmeye başlanmıştır. Bu belge, turizm işletme belgeli olan ve çevreye karşı duyarlı faaliyet gösteren işletmelere uygulandığı bilinmektedir. Böylece işletmelere, enerji azaltılması ve enerji verimliliğin arttırılması, çevreye zararlı madde kullanımlarının azaltılması gibi konularda teşvik sağlandığı görülmektedir (http://www.ktbyatirimisletmeler.gov.tr, e.t. 05.11. 2014).

Türkiye Otelciler Federasyonu (TÜROFED), Beyaz Yıldız projesini başlatarak çevrenin korunması ve sürdürülebilirliğin sağlanmasını hedeflediği bilinmektedir. Ayrıca; turizm işletmelerinde kontrolsüz kullanılan su, elektrik, katı atık, sıvı atık vb. kontrol altına alınması ve düzenlenmesi bir diğer amaç olarak 
Yalova Sosyal Bilimler Dergisi

belirtilmektedir (Kız1lırmak, 2011: 10). Bununla birlikte, bu projeyle kontrolsüz tüketim yerine bilinçli bir tüketime dönüştüren ve gerekli kriterleri sağlayan işletmeler Beyaz Yıldız alabilmektedir (Tutar, 2015: 341).

AK Parti iktidarı döneminde gerçekleştirilen ve turizm endüstrisini etkileyen bir diğer gelişme; aktif havaalanı sayısının 26'dan 53'e çıkarılmasıdır. Böylece havayolunu kullanan toplam yolcu sayısı daneredeyse 4 kat artarak 150 milyona ulaşmıştır. 2002 yılında 150 olarak bilinen toplam uçak sayısı 2014 itibariyle 400'e ulaşmıştır. Bununla birlikte, İstanbul Atatürk Havalimanı'nın, 2014 yılı itibariyle hava ulaşımındabağlanabilirlikartışıyla dünyada birinci konuma yükselmiştir (62. Hükümet Programı, 2014: 158).

Kırsal kalkınma konusunun $\mathrm{AB}$ 'nin gündeminde her zaman yer aldığ bilinmektedir. $\mathrm{AB}$ 'ye uyum sürecinde Türkiye, kırsal kalkınmada da $\mathrm{AB}$ projelerini uygulamaya çalışmaktadır. Türkiye'de, kırsal turizmin geliştirilmesi çerçevesinde genel itibariyle sürdürülebilir turizm ve turizmin çeşitlendirilmesi (yayla turizmi, golf turizmi, ekoturizm gibi) konularına ağıllık verilmekte ve bu hususta $\mathrm{AB}$ destek projelerinden yararlanılmaktadır. Bununla birlikte, Katılım Öncesi Mali Araç-Kırsal Kalkınma Bileşeni (IPARD) uygulaması geliştirilmiştir. IPARD kapsamında, Türkiye, kırsal kalkınma sağlanacak iller için $A B$ fonlarının yönetimine dair koşulsuz yetki devri almıştır. Bu bağlamda; 2013 yılında 134 milyon Avro AB fonunun faydalanıcılara ödenmesi de bu uygulamadaki gelişmeye kanıt niteliğindedir (2014 İlerleme Raporu, 2014: 33).

Sosyal turizm kapsamına bakıldığında AK Parti döneminde, bireylerin ve özellikle engellilerin yaşam şartlarının (sağlık, ekonomi, sosyal vb. alanlarda) iyileştirildiği görülmektedir. Bu bağlamda, engelli vatandaşların yaşamlarını kolaylaştırmak için şehirlerin fiziki çevrelerini engellilere uygun şekle getirmek maksadıyla çeşitli projelerin başlatıldığı görülmektedir. Böylece engelli vatandaşlar daha rahat bir şekilde sosyal hayata adapte olacaklardır. Ayrıca, AK Parti iktidarı, kamuda engelli istihdamını önceki yıllara oranla beş katına çıkardığını belirtmiştir. Bununla birlikte, engellilerineğitim kurumlarına taşındığı ve özel eğitim hizmeti programlarıhazırlanarak uygulamaya geçirilmektedir. 2002-2013 yılları arasında bu hizmetlerden neredeyse 1,9 milyon engelli vatandaşın faydalandağ diğer bilgidir (62. Hükümet Programı, 2014: 75-76).

Türkiye, Avrupa Kültür Şehri (Başkenti) programına dâhil olmuş ve İstanbul 2010 Avrupa Kültür Başkenti Ajansına göre, bu program çerçevesinde, yaklaşık10 milyon kişinin katılımıyla, toplamda 10.000 civarında etkinlik düzenlenmiştir. Bununla birlikte, Türkiye, 9 Mayıs 2011 tarihinde yapılan Avrupa Günü kutlama etkinlikleridebulunmaktadır (2011 İlerleme Raporu, 2011: 98).

AK Parti döneminde kültür alanında harekete geçirilen birçok uygulamayla birlikte, 2014 y1lı itibariyle Dünya genelinde UNESCO Dünya Miras Listesi'ne kayıtlı 1007 kültürel ve doğal varlık bulunmaktadır. Bu değerlerden, 779 tanesi kültürel, 197 tanesi doğal, 31 tanesi ise karma (kültürel/doğal) varlık olarak açıklanmıştır. 2016 yılı itibariyle ise kayıtlı 1052 kültürel ve doğal varlık bulunmakta olup bunların 814 tanesi kültürel, 203 tanesi doğal, 35 tanesi ise karma (kültürel/doğal) varlık olarak nitelendirilmektedir. Bununla birlikte, Türkiye'nin, UNESCO Dünya Miras Listesi'ne 16 adet varlığı alınmıştır (http://www.kulturvarliklari.gov.tr/TR,44423/, e.t. 05.09.2016). 
AK Parti 10. Kalkınma Planı kapsamında kültür endüstrilerinin geliştirilmesi ile kültürel miras alanları için saha yönetim planlarının hazırlanması ve bu alanların restorasyonukonularını gündemine almıştır. Bu bağlamda, iktidarın kültürel alandaki atılımları giderek artırdığı ve önemli bir konu olarak değerlendirdiği söylenebilir (2014 İlerleme Raporu, 2014: 68).

Tüketicinin Korunması ve Piyasa Gözetimi Genel Müdürlüğü, çevrimiçi hizmetlerini gün geçtikçe kalitesini artırarak geliştirmekte ve tüketicinin korunması için yoğun çaba harcamaktadır. Bu bağlamda, farkındalık uyandırma ve tüketici eğitimine dair etkinlikleri arttırdığı bilinmektedir. Ayrıca, AB müktesebatına uyum sağlanması amacıyla Tüketicinin Korunması Hakkında Kanun Mayıs 2014 yılındayürürlüğegirmiştir (2014 İlerleme Raporu, 2014: 70).

Tüketicinin korunması alanında bazı ilerlemelerin olduğu; ancak tüketici haklarının uygulamaya geçirilmesinin bütün düzeylerde iyileştirilmesi zorunlu bir unsur olarak karşımıza çıkmaktadır. Bu nedenle, tüketiciye yönelik iyileştirme hareketlerinin devam etmesine rağmen henüz yetersiz kaldığg görülmektedir (2014 İlerleme Raporu, 2014: 71). Bu bağlamda, tüketici hakları kapsamına giren turist hakları hususunun da yetersiz kaldığı bilinmektedir.

2014 İlerleme Raporu'na göre Serbest Dolaşım Politikası kapsamında Türkiye'nin $\mathrm{AB}$ vize gereklilikleri ve muafiyetlerine adapte olmas1 ve vize politikasını AB üye devletleri ile uyumlu hale getirmesi gerekmektedir (2014 İlerleme Raporu, 2014: 64).

Mesleki Turizm Eğitim ve Öğretiminin Desteklenmesi açısından Türkiye'nin, eğitim, mesleki eğitim ve gençlik konularında, $A B$ müktesebatı ve standartlarına uyum sağlama çabalarının devam ettiği görülmektedir. Bu bağlamda, $\mathrm{AB}$ müktesabatına uyum amaciyla, meslek standartlarını belirlemeye ve belgelendirmeye yönelik düzenlemeler kapsamında, Mesleki Yeterlilikler Kurumu kurulduğu ve 560 ulusal meslek standartları oluşturulmuştur (62. Hükümet Program1, 2014: 129-130).

Eğitim, öğretim ve gençlik alanında, yüzde 55'i AB tarafından finanse edilen Hayatboyu Öğrenme ve Gençlik Programlarına yapılan başvurular giderek artmaktadır. Bununla beraber, kurum ve kişilerle imzalanan hibe anlaşmalarının 3.600 'den fazla olduğu ve nihai fayda sağlayanların ise toplam sayıları neredeyse 70.000'e ulaşmıştır. Bu bağlamda, Türkiye, Mayıs 2014 yılında "Erasmus+" programına tam katılım için anlaşma imzalandığı bilinmektedir. Ayrıca, Türkiye'nin bazı üniversitelerinde Bologna Süreci, uygulama açısından ileri olduğu; ancak Türkiye'deki üniversiteler arasında nitelik bakımından da önemli farklılıklar olduğu belirtilmektedir (2014 İlerleme Raporu, 2014: 67).

Türkiye'de turizm ve işletmecilik alanında eğitim veren, üniversiteler (iki veya dört yıllık) ve meslek liseleri bulunmaktadır. Bu birimler, Avrupa Birliği’ne uyumlu yeni müfredatlar oluşturarak ve uygulamaya geçirerek eğitimlerini devam ettirmektedirler. Ayrıca, Avrupa Birliği'ne üye ülkelerle ortak çalışmalar, projelere katılım sağlamaktadırlar.

Uluslararası Pazarda Avrupa Turizminin Tanıtılmas1; Türkiye, AB'ye katılım sürecinde, Avrupa Birliği Uyum Yasaları uyarınca turizm politikalarını değiştirmeye ve AB'ye uyum sağlamaya yönelik çalışmalar gerçekleştirmektedir. 
Yalova Sosyal Bilimler Dergisi

Bu uyumu sağlayabilmek amaciyla, Avrupa turizm şehirleriyle rekabet edebilecek bir turizm endüstrisi meydana getirmenin gerekli olduğu açıklanmıştır. Buna istinaden, turizm politikalarıyla birlikte, kültür ve turizm tanıtımında yeni ve güncel düzenlemelerle iyileştirmelerin yapılmasının şart olduğu bilinmektedir (Çakır ve Yalçın, 2014: 8-9).

Türkiye'nin uluslararası pazarda turizm adına tanıtımının ve pazarlanmasının yapılması, ziyaretçilere ülkenin kültür ve değerlerinin öğretilmesi anlamına gelmektedir. Böylece, turizmin ve ülkenin tanınırlığ 1 artarak, pazardaki payını büyütecektir. Turizm endüstrisine dair tanıtımların genel olarak Kültür ve Turizm Bakanlığı tarafindan yapılmakta ve Bakanlığa, turizm ile doğrudan veya dolaylı olarak yeralan birçok kurum ve kuruluş destek vermektedir.

Bununla birlikte, Türkiye'nin, UNESCO Dünya Miras Listesi'ne 16 adet varlığıgirmeyi başarmıştır. Turizm İstatistiklerinin geliştirilmesi; turizm verilerin toplanması ve AB'ye üyeülkeleregönderilmesi, bu verilerin diğer üye ülkelerin verileriyle karş1lklı incelenmesi amacıyla turizm istatistikleri için bir sistem oluşturulması gerekliliği savunulmuştur. Bu bağlamda, Eurostat (Avrupa İstatistik Ofisi) tarafindan turizm de kapsayan istatistiklerin geliştirildiği görülmektedir. Avrupa Birliği'ne istatistikler sağlamayı amaçlayan bu kurum, Türkiye'nin turizm verilerini de yayınlamaktadır.

2005 y1lında Türkiye'de “Türkiye İstatistik Kurumu (TÜİK)” kurulmuş ve turizm sektörü kapsamındaki verilere, bu kurum aracılığıyla ulaşılacağı açıklanmıştır. Bununla birlikte, Turizm ve Kültür Bakanlığı ile Türkiye İstatistik Kurumu'nun işbirliği ile yapılan istatistikler Kültür ve Turizm Bakanlığı Yatırım ve İşletmeler Genel Müdürlüğü'nün sitesinde de yayınlanmaktadır. Bu istatistikler, turist geceleme, giriş-çıkış, yat, turizm gelir-gider ve harcama gibi turizm endüstrisine dair konuları kapsamaktadır.

İstatistiki altyapı hususundaki faaliyetlerin artırılması için, TÜİK'te kapsamlı bir şekilde yeniden yapılandırma çalışmalarının başlatıldığı açılanmıştır. Ayrıca, turizm istatistikleri için, TUIK, turizm istatistiklerine dair metodolojisini yeniden değerlendirerek $\mathrm{AB}$ metodolojisi ile daha uyumlu hale getirildiği ve $\mathrm{AB}$ müktesebatıyla uyumun ileri aşamada olduğu belirtilmiştir (2014 İlerleme Raporu, 2014: 40).

\section{Sonuç}

Turizm, ekonomi, kültür, çevre, istihdam, kırsal kalkınma gibi alanlarla yakından ilgili olan bir endüstri olarak bilinmektedir. İlk başta sadece istihdam, bölgesel kalkınma alanlarına olan faydalarıyla bilinmiş olsa da, ilerleyen yıllarda ekonomiye olan katkısının daha fazla olduğu keşfedilmiştir. Böylece, dünya üzerinde turizm endüstrisinin gelir meydana getirici özelliği ortaya çıkmış ve turizme olan ilgi artmıştır. Ekonomik katkısı yanında turizm endüstrisi, sosyal, kültürel, kırsal vb. etkisi ile pazardaki yerini güçlendirmiştir. Böylece hem ekonomilerini hem de diğer niteliklerini geliştirmek isteyen ülkeler turizm alanına yönelmeye başlamıştır. 
Yalova Sosyal Bilimler Dergisi

$\mathrm{AB}$ ülkeleri, dünya üzerinde, önemi büyük ve en çok tercih edilen destinasyon olarak bilinmektedir. $\mathrm{AB}$, hala ortak bir turizm politikası oluşturmamasına rağmen, turizm alanında birçok atılım yaparak, önemli oranda destek vermiştir. Turizm endüstrisine, özellikle, çevre, kırsal, sosyal, ulaştırma, eğitim gibi alanlarda projeler oluşturarak ve bu projelere maddi açıdan da katkı sağlayarak teşvik vermiş̧tir. Bu bağlamda, AB'nin ortak politika oluşturmasa da, diğer başlıklar altında turizm adına uygulamalar yaptığı görülmektedir.

Türkiye'nin, turizm endüstrisine hizmet verebilecek doğal, kültürel birçok alana sahip olduğu bilinmektedir. Ayrıca, Turizmi Teşvik Kanunu'nun çıkarılması turizme katkı sağlayan önemli bir gelişmedir. Bununla birlikte, Türkiye'de uygulamaya başlanılan Beş Yıllık Kalkınma Planları (1963) ile turizmin dikkate alındığı ve gelişmeye başladığı anlaşılmaktadır. Turizmin geliştirilebilmesi amacıyla, çeşitlendirilmesi, özel ve kamu sektörü değerlendirmeleri, doğal alanların sürdürebilirliğinin sağlanması, turizmin tanıtılması gibi bir çokalanda düzenlemeler yapılmaktadır. Ayrıca, turizm endüstrisinin ödemeler dengesine olan katkısının farkedilmesi en önemli ayrıntılardan biri olarak dikkati çekmektedir.

Türkiye'nin, atılımlarını ve çalışmalarını devam ettirmesine rağmen, AB'de olduğu gibi, turizm endüstrisine yönelik istikrarlı bir politikayı henüz oturtamamıştır. Bununla birlikte, turizme destek vermek ve katkı sağlamak amacıyla, dolaylı veya doğrudan birçok kurumla ortak bir şekilde çalışmalarını sürdürmektedir.

AK Parti'nin iktidar olduğu 2002'den 2016 sonuna kadar olan zamanda turizm adına yaptığı çalışmaların birçoğuolumlu sonuçlar vermiştir. AK Parti iktidarı, 2005 yılında AB'ye tam üyelik müzakerelerine başlamış ve böylece diğer alanlarda olduğu gibi turizm endüstrisinde de $A B$ 'ye uyum sağlama politikasıyla ilgili düzenleme ve planlamaları çalışmalarına daha da derinlemesine dahiletmiştir.

AB'nin çevre politikası kapsamında değerlendirdiği sürdürülebilir turizm, kırsal turizm, turizmin çeşitlendirilmesi, AB'nin finansman sağladığı projeler gibi konularda, AK Parti iktidarında çeşitli eylem ve tutumlar geliştirilmiştir. AK Parti döneminde Mavi Bayraklı plajların artışı, AB Entegre Çevre Uyum Stratejisi, Ulusal İklimDeğişikliği Strateji Belgesi, Atık Yönetimi gibi eylemlerhayata geçirilmiştir ve hala da çalışmalar devam ettirilmektedir.

AK Parti, turizmin en önemli halkası olan ulaştırma alanında da yenilikler gerçekleştirmiştir. Havalanı sayısının artışı, uçak sayısının artışıyla ziyaretçi sayısının yükselmesi bu yenilikler arasında yer almaktadır. Böylece, rekabet ortamının olmasıyla bilet fiyatlarının ucuzlaması da kişileri seyahate yönlendirecektir. Özellikle AK Parti döneminde hava alanı saysındaki artışlar turizmin gelişmesine oldukça katkı yapmıştır. İstanbul'da yapımı devam eden üçüncü havaalanının tamamlanması ise bu bağlamda çok bütük katkı sağlayacaktır. Karayollarının iyileştirilmesi, modernize edilmesi, yenilerinin yapılması da aynı etkiyi doğurmaktadır.

Türkiye'yi turizm açısından geliştirmek ve tanıtmak amacıyla restorasyon, proje, tarihi eser uygulamaları gerçekleştirilmiştir. Bu kapsam da Türkiye'nin turizm açısından çekiciliğinin artması ve merak uyandırması sağlanmıştır. AK Parti iktidarı, özel ve kamu işbirliğinde sürdürdüğü projelerinin bir kısmını bitirmiş olup, sürekli 
Yalova Sosyal Bilimler Dergisi

yeni eğilim içerisinde bulunmaktadır. Ayrıca, kişilerin sosyal ve ekonomik açıdan yaşam şartlarını iyileştirerek bu kişilerin endüstriye katılımlarını sağlamıştır. Bununla birlikte AK Parti iktidarı, özellikle AB'nin de üzerinde durduğu, engelli vatandaşların sosyal hayata uyum sağlamaları için şehirlerde uygun alanların oluşturulmasına büyük önem vermektedir.

Ayrıca sosyal ve görsel medyada Türkiye'nin tanıtımına özel önem verilmesi, spor müsabakalarında ve çeşitli eğitim, sanat, sosyal ve ekonomik alandaki başarıları uluslararası alanda duyurma çabaları da Ak Parti döneminde özel önem veren hususlar olarak Türk turizminin gelişmesine özel katkı sağlamıştır. Turizme verilen diplomatik ve politik desteklerin olumlu sonuçları alınmaktadır.

AK Parti, AB'ye uyum sağlamak amaciyla, Tüketicinin Korunması Hakkında Kanun 2014 yılında yürürlüğe koymuştur. Ayrıca, AK Parti iktidarı, mesleki eğitim konularına verdiği önemle de dikkati çekmiştir. Bu dönemde, $A B$ standartlarına uygun olarak mesleki standartlar belirlenmiş ve turizm de bu standartlar içerisinde yerini almıştır. Mesleki standartlarlarla birlikte, AB'nin finanse ettiği programlara katılım oranının artışının sağlandığı da elde edilen bir diğer bilgidir.

$\mathrm{AB}$, turizme hizmet veren ülkelerin karş1lıklı değerlendirmelerinin yapılması amacıyla istatistik bilgi alınabilecek bir sistem olması gerektiğine vurgu yapmıştır. Böylece istatistiki bilgilerin alınabileceği topluluk oluşturulmuştur. Türkiye'nin turizm verileri de bu kurum tarafindan yayınlanmaktadır. Ayrıca, 2005 yılında kurulan Türkiye İstatistik Kurumu'da turizm verilerini hizmete sunmaktadır. Bu bağlamda, AK Parti iktidarının, istatistiki bilgilendirme konusunda, AB ile uyum aşamasında başarılı çalışmalar gerçekleştirdiği ortaya çıkmaktadır.

AB'nin serbest dolaşım politikası, üye ülkelerde hiçbir engel olmadan kişilerin veya yatırımcıların kalması ve çalışması gibi hususları kapsamaktadır. Ancak, Türkiye'nin vize muafiyetleri konusunda atılımlar gerçekleştirmesine rağmen, henüz herhangi bir sonuç elde edememiştir. Bununla birlikte, AK Parti iktidarı, şuan herhangi bir sonuç olmasa da çalışmalarına ve girişimlerine devam etmektedir.

AB'ye üyelik sürecinde, AK Parti iktidarının diğer birçok alanda olduğu gibi turizm endüstrisine de gereken önemi verdiği anlaşılmaktadır. Turizm hareketlerine katılan ziyaretçi sayılarının artışı ve ekonomik kalkınma bu durumun kanıtı niteliğindedir. Ayrıca, $\mathrm{AB}$ müktesabatına uyum süreci, yapılan düzenlemeler, katılım sağlanan toplantılar, projeler ve alınan hibe destekleriyle gelişmeye devam etmektedir. 
Yalova Sosyal Bilimler Dergisi

\section{Kaynakça}

Alaca, B. A. (1997), Turizm Politikası, Turizmin Türk Ekonomisindeki Yeri, Sorunları ve Çözüm Önerileri, Yüksek Lisans Tezi, Cumhuriyet Üniversitesi, Sosyal Bilimler Enstitüsü, Sivas.

Arslan, F. (2014), 'Avrupa Birliği' nin Turizm Politikası ve Türkiye Turizm Stratejsi 2023 Üzerine Bir Değerlendirme’, Uluslararası Sosyal Araştırmalar Dergisi, 7(31), s.427-438.

Ateşoğlu, L. (2006), Avrupa Birliği Turizm Politikası ve Avrupa Birliği ile Türkiye Turizm SektörleriÜzerine Etkileri, Yüksek Lisans Tezi, MuğlaÜniversitesi, Sosyal Bilimler Enstitüsü, Muğla.

Avcıkurt, C. (1997). Avrupa Birliği ile BütünleşmeSürecindeTürk Turizmi (Sorunlar ve ÇözümÖnerileri), Doktora Tezi, Balıkesir Üniversitesi, Sosyal Bilimler Enstitüsü, Balıkesir.

Avrupa Akademik Çalışmalar Merkezi (2014), “AB'de Ortak Turizm Filizleniyor”, http://www.euroacademic.org/tr/index.php?act=show\&code=page \&id=90 \&id_page $=134 \&$ resume $=0 \&$ page $=2 \&$ car $=3740($ Erişim Tarihi 10.11.2014 $)$.

Avrupa Birliği Bakanlığı (2013), 'Türkiye Tarafından Hazırlana 2013 İlerleme Raporu', ss.1-243.

Avrupa Birliği Bakanlığı (2014), 'Türkiye Tarafından Hazırlana 2014 İlerleme Raporu', ss.1-76.

Avrupa Birliği Bakanlığı (2015), ‘Türkiye 2015 İlerleme Raporu', ss.1-98.

Avrupa Komisyonu Genişleme Genel Müdürlüğü (2011), 'Genişleme Stratejisi ve Başlıca Zorluklar 2011-2012 \{COM(2011) 666\} Türkiye 2011 Y1lı İlerleme Raporu', ss.3-110.

Avrupa Komisyonu Genişleme Genel Müdürlügü (2014), 'Genişleme Stratejisi ve Başlıca Zorluklar 2014-2015 \{COM(2014) 700$\} 2014$ İlerleme Raporu, ss.376.

Başbakanlık(2014),http://www.basbakanlik.gov.tr/Forms/_Global/_Government/pg _GovernmentProgram.aspx (Erişim Tarihi 5.11.2014)

Beken O.O. (2007), ‘Avrupa Birliği Mali ve Turizm Politikaları, Türkiye Turizm Endüstrisine Olası Etkileri, Antalya İline Yönelik Uygulama', Yüksek Lisans Tezi, Süleyman Demirel Üniversitesi, Sosyal Bilimler Enstitüsü, Isparta.

Commission of the European Communities (2002), 'Commission Staff Working Paper Report On Community Measures Affecting Tourism (2000) (Sec 2002/300)', Brussels: Commission of the European Communities, ss.4-52.

Commission of the European Communities (1991), 'Community Action Plan To Assist Tourism (Com 91/97) Final', Brussels, ss.1-47.

Commission of the European Communities (1996), 'The Regions on Community Measures Affecting Tourism (Com 1996/29) Final', Brussels, ss.1-127. 
Yalova Sosyal Bilimler Dergisi

Commission of the European Communities (1995), 'The Role of theUnion in the Field of Tourism (COM 1995/97) Final', Brussels: Commission of the European Communities, ss.1-74.

Commission of the European Communities (2004), 'Report on the Implementation of the Community Programmes Kaleidoscope, Arianeand Raphael (COM 2004 /33) Final', Brussels, ss.3-14.

Çiçek, O. ve Özgen, I. (2001), 'Avrupa Birliği'nde Turist Hakları ve Adaylık Sürecinde Türkiye'deki Uygulamalar', Dokuz Eylül Üniversitesi Sosyal Bilimler Enstitüsü Dergisi, 3 (3), ss.139-153.

DPT (Devlet Planlama Teşkilatı) (2006), 'Dokuzuncu Kalkınma Planı (2007-2013)', Turizm Özel İhtisas Raporu (24 Ocak), Ankara, ss.9-70.

EC (European Communities) (December 1995, L 291/36), 'Directive 95/57/EC of 23.11.1995 on the Collection of Statistical Information in the Field of Tourism, Official Journal of the European Communities', Brussels, ss.33.

EC (European Commission) (2006), 'Keep Europe Moving, Office for Official Publications of the European Communities', Luxembourg, ss. 3-25.

Emekli, G. (2005), ‘Avrupa Birliği’nde Turizm Politikaları ve Türkiye’de Kültürel Turizm’, Ege Coğrafya Dergisi, 14 (1-2), ss.100-107.

Hepaktan, E.ve Çınar, S. (2010), 'Turizm Sektörünün Türkiye Ekonomisi Üzerindeki Etkileri’, Celal Bayar Üniversitesi, Sosyal Bilimler Dergisi, 8(2), ss. $135-154$.

Karakuş, G. (2003), 'Avrupa Birliği Turizm Politikası (Tourism Policy Within The European Union)', Rapor No: 1276, İstanbul, Kültür ve Turizm Bakanlığı, ss.21.

Kızılırmak, İ. (2011), 'Dünyada ve Türkiye'deki Turizm İşletmelerinde Çevre Korumaya Yönelik Uygulamalar: Amac1 ve Önemi', Sosyal Bilimler Dergisi, (2), s.1-12.

Kolektif (Ekin Yazım Grubu, 2003a), 'AB'de Turizm, Turizm Yıllı̆̆ı: 2002 Verileri’, Fehmi Köfteoğlu, ss.32.

Kuşçu, S. (2011), “Avrupa BirliğiUlaştırma Politikası ve Türkiye'ye Yansıması”, Akademik Bakış Dergisi, 5(9), ss.77-91.

Çakır, M. ve Yalçın, A.E. (2012). Kültür ve Turizm Tanıtımında Bir Araç Olarak İnternet Kullanımı [elektronik versiyon. Teftiş Kurulu Başkanlığ l, TC Turizm ve Kültür Bakanlığı. 1-40.

Paksoy, P. (2005), Avrupa Birliği ile Bütünleşme Sürecinde Avrupa Birliği'nin Türk Turizminde Rolü ve Önemi, Doktora Tezi, İstanbul Üniversitesi, Sosyal Bilimler Enstitüsü, İstanbul.

Sivil, H. İ. (2007), Avrupa Birliği Turizm Politikaları ve Türkiye Turizmi, Yüksek Lisans Tezi, Firat Üniversitesi, Sosyal Bilimler Enstitüsü, Elazığ.

TBMM (Türkiye Büyük Millet Meclisi), 'II. Erdoğan Hükümeti Programı', http://www.tbmm.gov.tr/hukumetler/HP60.htm (Erişim Tarihi 04.11.2014). 
Yalova Sosyal Bilimler Dergisi

TBMM (Türkiye Büyük Millet Meclisi), III. Erdoğan Hükümeti Program1, http://www.tbmm.gov.tr/hukumetler/HP61.htm (Erişim Tarihi 04.11.2014).

T.C.Başbakanlık,'62.Hükümet Programı’, http://www.basbakanlik.gov.tr/Forms/_Global/_Government/pg_CabinetHi story.aspx (Erişim Tarihi 10.11.2014).

T.C.Başbakanlık, '65. Hükümet Programı', http://www.basbakanlik.gov.tr/Forms/_Global/_Government/pg_CabinetHi story.aspx (Erişim Tarihi 05.11.2016).

T.C. Kültür ve Turizm Bakanlığı Yatırım ve İşletmeler Genel Müdürlüğü, 'Çevreye Duyarlılık Kampanyası (Yeşil Yıldız), http://www.ktbyatirimisletmeler.gov.tr/TR,11596/cevreye-duyarlilikkampanyasi-yesil-yildiz.html (Erişim Tarihi 05.11.2014).

T.C. Kültür ve Turizm Bakanlığ1, 'Dünya Miras Listesi', http://www.kulturvarliklari.gov.tr/TR,44423/dunya-miras-listesi.html (Erişim Tarihi 6 Kasım 2014)

Tutar, F.K. (2015), 'Yeşil Ekonomi, Yeşil Turizm: Türkiye'de Turizm Sektöründe Yeni Trend Yeşillenen Oteller Projesi', Akademik Sosyal Araştırmalar Dergisi, 3 (13), s. 328-352.

Türkiye İstatistik Kurumu Avrupa İstatistik Sistemi, 'Avrupa İstatistik Sistemi', http://www.tuik.gov.tr/arastirmaveprojeler/uluslararasi/ab/ab_sistem.html (Erişim Tarihi 24.11.2014).

Ural, H. (2008), 'Türkiye ve Avrupa Birliği Arasındaki Turizm İlişkileri Çerçevesinde Turizm Değerlerine ve Sektöre Yönelik Türkiye ve Avrupa Birliği Politikalarının Değerlendirilmesi', Uzmanlık Tezi, Kültür ve Turizm Bakanlığı, Dış İlişkiler ve Avrupa Birliği Koordinasyon Dairesi Başkanlığ1, Ankara.

Ünal, A. B. (2007), 'Türkiye'nin Avrupa Birliği Turizm Politikasına Uyumu', Yüksek Lisans Tezi, Bahçeşehir Üniversitesi, Sosyal Bilimler Enstitüsü, İstanbul.

Verheugen, G. (2005), 'A Renewed EU Tourism Policy: Towards a Stronger Partnership for European',Tourism, 4th European Tourism Forum, 20 Ekim 2005, Speech/05/626, Malta.

Yağc1, Ö. (2003), Turizm Ekonomisi, Ankara: Detay Yayıncılık.

Yanardağ, Ö.ve Avc1, M. (2012), 'Turizm Sektöründe İstihdam Sorunları: Marmaris, Fethiye, Bodrum İlçeleri Üzerine Ampirik Bir İnceleme', Ege Stratejik Araştırmalar Dergisi, 3(2), s. 39 - 62. 